\title{
THEORY AND HISTORY OF POLITICS
}

\section{DOI https://doi.org/10.30525/978-9934-26-120-6-11}

\section{ПОЛІТИЧНЕ ПОЛЕ ГРОМАДЯНСЬКОЇ ВІЙНИ}

\author{
Вовк С. О. \\ доктор політичних наук, доцент, \\ завідувач кафедри політологї та правознавства \\ Державний заклад «Луганський начіональний університет \\ імені Тараса Шевченка» \\ м. Старобільськ, Луганська обл., Украӥна
}

Сутність громадянської війни - це боротьба за владу. До специфічних ознак громадянської війни відносять такі, як: наявність соціальних, політичних, ідеологічних, міжнаціональних, релігійних, міжособистих протиріч, напружених, взаємознищуючих відносин між протиборчими сторонами; глибоке соціальне розшарування суспільства, що має характер гострої поляризації соціально-групових інтересів; наявність у всіх протиборчих сторонах апарату управління, воєнно-політичного механізму; застосування практики демократичних режимів, що не мають загальновизнаної національної легітимності; революційний радикалізм, максималізм i нетерпимість окремих політичних сил, що намагаються завоювати владу; практика різкої, незаконної зміни політичного курсу державної еліти суспільства; необгрунтовані, необмежені політичні амбіції, воля до влади та інші психологічні фрустрації окремих політичних кланів та їхніх лідерів; прихід до влади сил, що не виражають у політиці загальнонаціональні інтереси; відкидання більшості складників законності та політичної демократії; ерозія державного суверенітету, яку можна вважати зовнішнім стресом; залежність від втручання глобальних і регіональних акторів (відмова від міжнародної підтримки, економічна і політична блокада і т. п.).

Враховуючи підходи П. Бурдье [1], Ю. Качанова [2], Д. Ротмана [3], М. Розова [4], що політичне поле визначається як поле сил та поле політичної боротьби, спрямованої на зміну співвідношення цих сил, яке, в свою чергу, визначає структуру поля в певний конкретний момент i не зводиться виключно до держави, можна надати характеристику політичного поля громадянської війни, яка відображає 
екстраординарний етап зміни суспільної-політичної системи держави, що спричинений антагоністичними протиріччями і в якому протиборчі сторони спрямовують свої дії на захоплення / збереження влади, повалення / консервування чинних політичних структур, політичного i фізичного знищення супротивника.

До основних характеристик політичного поля громадянської війни варто віднести:

По-перше, це реальний простір, який охоплює територію певної держави, в межах якої відбувається протистояння протилежних ідеологічних концепцій протиборчих сторін, які пропонують населенню свої шляхи майбутнього розвитку та прагнуть отримати / зберегти владні повноваження правовими та / або неправовими методами.

По-друге, внутрішній простір політичного поля за схемою «авансцена - ядро - периферія» в умовах громадянської війни представлений: а) суб'єктами-індивідами (лідерами, керівниками, державними і політичними діячами, головнокомандуючих збройних сил) та суб'єктами-колективними (соціальними групами, соціальними верствами, політичними організаціями, які який мають певний політичний ресурс, свої політичні інтереси і здатні їх відстоювати у збройному протиборстві за владу); б) учасниками-прихильниками (групами суспільства та соціальними прошаркам, які приймають активну участь в політичних подіях громадянської війни); в) політично пасивними громадянами.

В межах даної схеми реалізується основна ціль політичного поля набуття домінантної власної позиції.

По-третє, одночасно політичне поле громадянської війни є полем збройної боротьби (протиборчі сторони вже використовують зброю, готові вбивати і загинути за свою політичну продукцію) та полем війни (наявність у всіх протиборчих сторонах апарату управління, воєннополітичного механізму, використання сторонами методів i конвенційної, і неконвенційної стратегії на тлі великої глибини соціальних протиріч у суспільстві).

По-четверте, в умовах громадянської війни вирішальним $є$ не поодиноке зіткнення, а увесь каскад множинних і взаємопов'язаних низок подій. Відповідно, головними результатами $є$ зміни співвідношення сил, їхньої легітимності, що зафіксовано в інституціальних змінах в сфері влади, контролю над насиллям i доступу до ресурсів. 


\title{
Література:
}

1. Бурдье П. Социология политики / пер. с фр. Soio-Logos. Москва, 1993. $336 \mathrm{c}$.

2. Качанов Ю. Агенты поля политики: позиции и идентичность. Вопросы социологии. 1992. № 2. URL: http://sociologos.net/voprosisociologii-2-1992.

3. Ротман Д. Политическое поле изменяющегося государства: структура, особенности функционирования и возможности социологического исследования. Сочиология. 2004. № 4. С. 31-42.

4. Розов Н. Концепция конфликтной динамики и главные развилки февральской революции. Вестник Томского гоударственного университета. 2017. № 421. С. 41-52.

\section{DOI https://doi.org/10.30525/978-9934-26-120-6-12}

\section{КОНЦЕПТОСФЕРА ПОЛІТИЧНОЇ НАУКИ І МЕНТАЛЬНІ КАРТИ: СИНТЕЗ НАУКОВИХ І ПОПУЛЯРНИХ ПІДХОДІВ ДО ДОСЛІДЖЕННЯ ПОЛІТИКИ}

\author{
Яковлєв М. В. \\ кандидат політичних наук, дочент, \\ керівник НОЦ «Школа політичної аналітики», \\ завідувач кафедри міжнародних відносин \\ Начіональний університет «Києво-Могилянська академія» \\ м. Київ, Украӥна
}

Головною метою цієї доповіді $є$ демонстрація зв'язків методологічного рівня між ментальними (мисленнєвими або когнітивними як варіанти перекладу, або навіть «інтелект-картами») картами та дослідницькими підходами до аналізу й осмислення складових концептосфери політичної науки. Для досягнення цієї мети слід розглянути спершу ментальні карти, після чого стисло оглянути основні складові концептосфери політичної науки, і вже на основі цієї інформації виділити точки перетини між ними і можливий їх синтез на рівні методології.

Останнім часом поняття «ментальні карти», «мапи розуму» тощо дедалі частіше можна побачити у рекламних повідомленнях різних тренінгів, автори яких обіцяють розвиток мислення, покращенні когнітивних можливостей, а відтак навіть і суттєво кращий фінансовий 